\title{
MINERAL CHEMISTRY OF KAMAFUGITES AND RELATED ROCKS FROM THE ÁGUAS EMENDADAS REGION, GOIÁS STATE
}

\author{
TEREZA CRISTINA JUNQUEIRA-BROD ${ }^{1}$. JOSE AFFONSO BROD ${ }^{2}$, SALLY A. GIBSON $^{3}$ \\ AND ROBERT N. THOMPSON ${ }^{4}$
}

\begin{abstract}
In the Águas Emendadas Region, Goiás State, Brazil, Late Cretaceous alkaline magmatism produced a series of diatreme structures of kamafugitic affinity. These occurrences consist of a central breccia body, surrounded by lavas and intruded by dykes. Compositionally, the rocks vary from kamafugites, through melaleucitites and leucitites to basanites. The results of mineral chemistry study of olivine, clinopyroxene, feldspathoids, feldspars, perovskite, opaque minerals and carbonates confirms the kamafugitic character of the studied rocks and suggests a link with carbonatite magmatism.
\end{abstract}

Keywords Kamafugite; carbonatite; kalsilite; diatreme

INTRODUCTION The Águas Emendadas Region (AER) is located in southern Goiás State, central Brazil, approximately $450 \mathrm{~km}$ southwest of Brasília, between the towns of Amorinopolis and Montividiu. During the Late Cretaceous, alkaline and subordinate saturated magmas intruded both the Precambrian basement and the Phanerozoic sediments of the northern border of the Parana Basin, forming the Rio Verde-Ipora Igneous Province (RVIIP). A number of diatreme-like structures were generated during this event (JunqueiraBrod 1998; Junqueira-Brod et al. 1999). This paper focuses on the mineral chemistry of olivine, clinopyroxene, feldspathoids, feldspars, perovskite, opaque minerals and carbonates from the Águas Emendadas complex and two other similar diatreme structures in the region. The AER rocks contain kalsilite and show strong geochemical affinity with kamafugites (Junqueira-Brbd 1998). The abundance of carbonate in this association, and the presence of immiscibility-like features, such as carbonate globules, suggest a kamafugite-carbonatite association, as proposed by Brod (1999) and Brod et al. (2000) for the contemporaneous Alto Paranafba Igneous Province (APIP), in Minas Gerais State.

GEOLOGICAL SETTING Almeida $(1983,1986)$ associated the alkaline provinces occurring around the margins of the Parana Basin with an extensional tectonic event. This would have led to the emplacement, in a first stage, of alkaline rocks contemporaneous with the Parana basalts and, in a second stage, of the Late Cretaceous alkaline magmas. Based on seismic data, VanDecar et al. (1995) suggested that the Late Cretaceous magmatism was related to the Tristan da Cunha Mantle Plume, as an extension of the Early Cretaceous magmatic event that generated the Parana basalts. Gibson et al. (1997) suggested that the cause for the RVIIP magmatism is the Late Cretaceous initial impact of the Trindade Mantle Plume near the Ipora region.

The RVIIP comprises a wide variety of petrographic types. Volcanic rocks dominate in the south and intrusive bodies are more common in the centre-north (Bez et al. 1971, Danni 1978, Barbour et al. 1979, Caspar and Danni 1981, Danni and Caspar 1992, Danni et al. 1992).

Near the town of Amorinopólis, a perpotassic to sodic-potassic (Danni 1985) sub-volcanic association occurs. Its core is occupied by a cylinder-shaped intrusion of basanitic to tephritic composition. Ring and radial dykes of olivine leucite melanephelinites, melanalcitites and olivine nepheline melaleucitites preceded the main intrusion. The last event was degassing of the sub-volcanic reservoir, forming breccia pipes (Danni 1985). A katungite pipe, found to the southwest of the main intrusion, is the only katungite occurrence described from the region so far (Danni 1985, Danni and Caspar 1992, Danni and Caspar 1994).

An alkaline-carbonatite association was identified in the Santo Antonio da Barra region (Caspar and Danni 1981), located in the southern part of the RVIIP, comprising interleaved lavas and pyroclastic deposits. The petrographic types include analcimites, olivine analcimites, analcimitic breccias and carbonatitic pyroclastic rocks. Late-stage dykes and plugs include fourchites, melamonchiquites, phonolites and trachytes. A kamafugitic affinity has been suggested for the parental magmas of Santo Antonio da Barra rocks (Moraes 1984, 1988; Sgarbi et al. 1998).

Another important RVIIP volcanic association, occurring in the Águas Emendadas Region (AER), is the subject of this paper. It comprises lavas, dykes, plugs, and pyroclastic deposits, emplaced into sandstones of the Aquidauana Formation and covered by sedimentary rocks of the Bauru Group. Compositionally, the AER lavas and dykes range from kamafugites, through melaleucitites and leucitites, to basanites.

FIELD RELATIONS AND PETROGRAPHY The diatreme structures found in the AER are infilled by breccias, composed largely of volcanic rocks and crystal fragments. In three localities studied during this work, they consist of a central body of breccia, with subordinate tuff, emplaced into the sedimentary rocks of the Parana Basin and surrounded by lavas. A small number of sinuous ultramafic dykes intrude the breccias.

The breccias consist of subangular blocks up to $3 \mathrm{~m}$ in diameter, scattered within a fragmental matrix with grainsize averaging $\sim 5 \mathrm{~mm}$ (1-50mm). Juvenile, cognate, accessory and accidental fragments are present. Highly vesicular, kamafugite, representing solidified magma pockets, composed of pyroxene, olivine, and perovskite microphenocrysts set in a very fine grained groundmass, are found within the breccias (Junqueira-Brod 1998). Irregularly shaped, "amoeboid" inclusions of a darker rock-type can be observed within the pockets, both in hand-samples and in thin sections. The inclusions have the same mineralogy as the host rock, but are more fine-grained and contain higher modal proportions of pyroxene, olivine and perovskite microphenocrysts.

Lavas occur as loose blocks on small hills around the breccias. Locally, flow banding is marked by the alignment of clinopyroxene phenocrysts. Vesicles are rare. The essential mafic minerals are clinopyroxene, olivine and, locally, melilite. Felsic constituents (leucite, kalsilite, and nepheline) are subordinate in most cases. Plagioclase is only modally important in the basanites. Common accessories are phlogopite, perovskite, Fe-Ti oxides, carbonate and apatite. The presence of "amoeboid" inclusions of variable size is noteworthy, these usually bear larger phenocrysts than their host lava. Cognate xenoliths are normally richer in phenocrysts than the enclosing lava. Xenoliths of cumulate rocks, such as pyroxenites and dunites, are also present.

The dykes are usually aphanitic but can vary locally to porphyritic facies, with phenocrysts of clinopyroxene (up to $2,5 \mathrm{~cm}$ ) and euhedral olivine (up to $1 \mathrm{~cm}$ ) set in a mostly aphanitic groundmass containing the same phases plus opaques and perovskite. Petrographically, these rocks are very similar to the kamafugite pockets found in the breccias, except in that they are less vesicular and poorer in amoeboid inclusions. Megacrysts of phlogopite are often found at the margins of the dykes. When present, vesicles are infilled by carbonate and zeolite, and tend to be concentrated in the central parts of the dyke. Scattered

1 Institute de Geociências-Universidade de Brasília; CEP 70919-970, Brasflia-DF; Brazil, e-mail: tcjbrod@unb.br

2 Departamento de Mineralogia e Petrologia - Institute de Geociências - Universidade de Brasília; CEP 70919-970, Brasflia-DF; Brazil e-mail: brod@unb.br

3 University of Cambridge, Dept. of Earth Sciences, Downing Street, Cambridge. CB2 3EQ. UK; e-mail: sally@esc.cam.ac.uk

4 University of Durham, Dept. of Geological Sciences, South Road, Durham. DH1 3LE. UK; e-mail: r.n.thompson@durham.ac.uk 
extremely fine-grained inclusions (up to $7 \mathrm{~mm}$ ) are present within the dykes.

A brief description of the main compositional types will be given in the sections below.

Kamafugites The AER kamafugites are poor in phenocrysts. The main phenocryst types are olivine and phlogopite, both often smaller then $2 \mathrm{~mm}$. Pyroxene phenocrysts are very rare. Olivine phenocrysts range in shape from perfectly euhedral to anhedral, the latter often showing clear evidence of disequilibrium. Phlogopite occurs as a poikilitic late phase, including groundmass minerals. The dominant dark grey groundmass is mostly microcrystalline, composed of nepheline, kalsilite, olivine, clinopyroxene, Fe-Ti oxides, perovskite and carbonate. Groundmass olivine is usually euhedral. Kalsilite and nepheline are restricted to the groundmass, occurring as small subhedral to anhedral crystals showing evidence of exsolution.

Melaleucitites The melaleucitites are strongly porphyritic. Some samples may contain small vesicles filled with carbonate. Cognate xenoliths of pyroxenite and dunite are very common. Olivine and strongly coloured (light brown to green) pyroxene are always the main constituents, with subordinate pseudo-leucite, phlogopite, perovskite, Fe-Ti oxides, apatite and nepheline.

Phenocrysts comprise olivine, pyroxene, phlogopite, perovskite and rare nepheline. Two generations of olivine phenocrysts are recognisable. One is euhedral, less than $3 \mathrm{~mm}$ in size, whereas the other may reach up to $1 \mathrm{~cm}$ and is mostly anhedral, showing evidence of resorption. Pyroxene phenocrysts are euhedral (up to $6 \mathrm{~mm}$ ), only occasionally showing signs of disequilibrium. Phlogopite phenocrysts are often partially or totally transformed into a microcrystalline mixture of Fe-Ti oxides, pyroxene, nepheline and olivine. Nepheline is rare as a phenocryst, always associated with phlogopite. Perovskite occurs as euhedral microphenocrysts in accessory amounts. Pyroxene and phlogopite phenocrysts often show inclusions of Fe-Ti oxides.

The groundmass is mostly composed of euhedral pyroxene microcrysts, followed in abundance by small crystals of pseudoleucite (anhedral to rounded "cloudy" patches) and euhedral microcrysts of Fe-Ti oxides. Euhedral perovskite, euhedral olivine, and small amounts of late-stage nepheline are the main groundmass accessories.

Leucitites This group is petrographically similar to the melaleucitites, except in the relative proportions of the essential phases. The main phenocrysts are leucite, pyroxene, olivine and phlogopite, in this order. All these phases are also present in the groundmass, pyroxene followed by leucite being the essential ones. Groundmass accessories are olivine, phlogopite, perovskite, Fe-Ti oxides, nepheline, apatite and carbonate. Cognate xenoliths of pyroxenite are also present.

Basalts and basanites This group comprises the only feldsparbearing volcanic rocks in the area. They range from aphanitic to strongly porphyritic. The main phenocryst phases are pyroxene (diopside, up to $1 \mathrm{~cm}$ ), olivine (usually euhedral, up to $5 \mathrm{~mm}$ ) and plagioclase (up to $1 \mathrm{~cm}$ ). The recognisable components of the groundmass are plagioclase, pyroxene, olivine, and rare nepheline.

MINERAL CHEMISTRY A study of the chemical composition of several minerals from the AER was carried out using a CAMECA SX50 electron microprobe at the University of Cambridge. The phases analysed comprise olivine, clinopyroxene, feldspathoids, feldspars, opaques and perovskite. Representative microprobe analyses are listed in Table 1 and trace-element ICP-MS analyses of carbonates are given in Table 2.

Olivine The molecular proportions of forsterite in the olivine range from $\mathrm{FO}_{76}$ to $\mathrm{Fo}_{88}$ ) which is consistent with the ultramafic character of the host rocks. Individual crystals may be zoned, with forsterite content decreasing from core to rim. Less frequently, a reverse pattern is observed. The reverse zoning suggests that some crystals are, in fact, a distinct generation of olivine that has been assimilated by a more magnesian magma. This is consistent with petrographic evidence for more than one variety of olivine phenocrysts. Groundmass olivines are usually less magnesian than the cores of olivine phenocrysts, but may overlap the composition of the phenocryst rims. $\mathrm{SiO}_{2}, \mathrm{NiO}$ (up to 0.37 wt.\%) and $\mathrm{Cr}_{2} \mathrm{O}_{3}$ (up to 0.1 wt.\%) correlate positively with the forsterite content, while $\mathrm{CaO}$ (up to $1.21 \mathrm{wt} \%$ ) and $\mathrm{MnO}$ (up to 0.73 wt.\%) show the opposite behaviour. The relatively low $\mathrm{NiO}$, and high $\mathrm{MnO}$ and $\mathrm{CaO}$ contents of some of the analysed olivines are comparable with those of olivine crystallising from carbonatites (Caspar et al. 1998), and may suggest a link with carbonatite magmatism.

Clinopyroxene All samples studied by microprobe contain clinopyroxene, as phenocrysts and/or in the groundmass. The relatively low Na content of these pyroxenes (up to $3.34 \mathrm{~mol} \%$ of the acmite molecule) allows their classification using the diagram for the fourcomponent system $\mathrm{CaMgSi}_{2} \mathrm{O}_{6}-\mathrm{CaFeSi}_{2} \mathrm{O}_{6}-\mathrm{Mg}_{2} \mathrm{Si}_{2} \mathrm{O}_{6}-\mathrm{Fe}_{2} \mathrm{Si}_{2} \mathrm{O}_{6}$ (Morimoto et al. 1988, Deer et al. 1992). In Fig. 1, most pyroxenes plot within or very close to the diopside field. The composition of pyroxenes from melaleucitites, kamafugites and leucitites largely overlap, but pyroxenes from basanites are slightly enriched in the hedenbergite molecule. One particular characteristic of AER pyroxenes is their very high $\mathrm{Ti}$ contents (up to 5.97 wt. $\% \mathrm{TiO}_{2}$ ), with $\mathrm{TiO}_{2}$ increasing from core to rim. Similar high-Ti clinopyroxenes have been described in Australian leucitites by Cundari and Salviulo (1989), who suggested that Ti-enrichment is favoured by lower temperature and higher oxygen fugacity. Fig. 2 compares AER clinopyroxenes with those from other alkaline rock-types and provinces. The $\mathrm{Al}$ content of most grains is higher than in lamproite pyroxenes. The $\mathrm{Al}$ range of AER pyroxenes is similar to those from the Roman Province and alkaline rocks from Paraguay, but the Ti/Al ratio is substantially higher in the AER. The best fit is with pyroxenes from kamafugites (Uganda), although the $\mathrm{Al}$ and Ti range of AER pyroxenes is wider.

Feldspathoids Two types of feldspathoids were found in the studied rocks. Nepheline was identified in samples of kamafugite, melaleucitite and leucitite. All nephelines have an unusually high content of $\mathrm{K}_{2} \mathrm{O}$, ranging from 9.45 to $11.17 \mathrm{wt} \%$. This corresponds to an excess of $\mathrm{K}$, in relation to the ideal nepheline formula (maximum of two $\mathrm{K}$ cations per 32 oxygen). The kalsilite molecule in these nephelines varies from 29.61 to $34.51 \mathrm{~mol} \%$. Kalsilite $\left(\mathrm{Ks}_{93.3}-\mathrm{Ne}_{6.6}\right.$, Table 2) was found in a kamafugite sample. XRD analyses confirmed that kalsilite is a modally significant mineral in this rocks.

Feldspars Alkali feldspars occur as part of pseudoleucite aggregates, finely mixed with nepheline, zeolites and carbonate in melaleucitites. The composition of these feldspars is close to the orthoclase end-member $\left(\mathrm{Or}_{96.498 .8}\right)$. Ba was not analysed, but the high analytical totals suggest it is riot present in significant amounts. Plagioclase was only found in basanites. It varies from $\mathrm{An}_{40.9}$ to $\mathrm{An}_{53.6}$, corresponding to calcic andesine and sodic labradorite. Some analyses may contain up to $1.46 \mathrm{wt} \% \mathrm{FeO}$, but this is probably related to the presence of impurities (Deer et al. 1992).

Perovskite Composition of AER perovskites is relatively restricted. During this work, only EDS analyses of perovskite were carried out. Therefore, it is not possible to directly evaluate the concentration of trace-elements such as the REE, $\mathrm{Nb}$ and $\mathrm{Sr}$, which would give origin to the end-members loparite, lueshite and tausonite, respectively (Mitchell 1996). However, the high analytical totals indicate that the analysed perovskites are relatively close to the ideal $\mathrm{CaTiO}_{3}$ composition. In fact, only $\mathrm{Si}, \mathrm{Al}, \mathrm{Fe}$ and $\mathrm{Na}$ occur as significant traces. When analyses are recalculated according to the general perovskite formula $\mathrm{ABO}_{3}$, calcium occupies 94 to $96 \%$ of the A site, and Ti occupies more than $99 \%$ of the B site. Thus, endmembers involving substitution of $\mathrm{Ti}$ (such as the $\mathrm{Nb}$-rich end member lueshite) are unlikely to be present in significant amounts. On the other hand, up to 4-6 mol \% of end-members that require substitution of other cations for $\mathrm{Ca}$ (e.g. the Na+REE-rich end-member loparite or the Sr-rich end-member tausonite) may be expected.

Opaques Opaque minerals generally occur as small groundmass grains, which makes the microprobe analysis difficult. Most of the analysed grains yielded a low analytical total, even after recalculation of the $\mathrm{Fe}^{3+} / \mathrm{Fe}^{2+}$ ratio to stoichiometry, according to the method of Droop (1987). This may be due to a) analytical error; b) the presence of non-analysed components or c) inaccuracy of the $\mathrm{Fe}^{3+} / \mathrm{Fe}^{2+}$ estimation method. Based mostly on semi-quantitative data, the 
Table J-Representative micropmbe analyses ofAER minerals, data from Junqueira-Brod(1998).

\begin{tabular}{|c|c|c|c|c|c|c|c|c|}
\hline $\begin{array}{l}\text { Mineral } \\
\text { Rock } \\
\text { wt.\% }\end{array}$ & $\begin{array}{r}\text { olivine } \\
\text { amafugite }\end{array}$ & $\begin{array}{l}\text { clinopyroxene } \\
\text { melaleucitite }\end{array}$ & $\begin{array}{l}\text { kalsilite } \\
\text { amafugite } \mathrm{r}\end{array}$ & $\begin{array}{r}\text { nepheline } \\
\text { nelaleucitite }\end{array}$ & $\begin{array}{r}\text { plagioclase } \\
\text { basanite }\end{array}$ & $\begin{array}{r}\text { K-feldspar } \\
\text { melaleucitite }\end{array}$ & $\begin{array}{l}\text { perovskite } \\
\text { kamafugite }\end{array}$ & $\begin{array}{l}\text { Ti-magnetite } \\
\text { melaleucitite }\end{array}$ \\
\hline $\mathrm{SiO}_{2}$ & 39.33 & 46.11 & 37.77 & 40.94 & 55.85 & 62.47 & 0.20 & 0.27 \\
\hline $\mathrm{TiO}_{2}$ & 0.03 & 3.82 & 0.08 & 0.09 & 0.44 & 0.15 & 58.38 & 27.56 \\
\hline $\mathrm{Al}_{2} \mathrm{O}_{3}$ & 0.00 & 5.78 & 30.52 & 33.21 & 26.62 & 18.70 & 0.30 & 2.32 \\
\hline $\mathrm{Cr}_{2} \mathrm{O}_{3}$ & 0.01 & 0.17 & 0.06 & 0.03 & 0.01 & 0.01 & 0.00 & 0.15 \\
\hline $\mathrm{Fe}_{2} \mathrm{O}_{3}$ & - & - & - & - & - & - & - & 14.01 \\
\hline $\mathrm{FeO}$ & 16.28 & 5.41 & 1.23 & 0.69 & 0.74 & 0.25 & 1.28 & 49.81 \\
\hline $\mathrm{MnO}$ & 0.28 & 0.17 & 0.06 & 0.00 & 0.01 & 0.00 & 0.03 & 0.90 \\
\hline $\mathrm{NiO}$ & 0.07 & 0.04 & 0.04 & 0.00 & 0.00 & 0.06 & 0.06 & 0.00 \\
\hline $\mathrm{MgO}$ & 43.57 & 13.31 & 0.22 & 0.12 & 0.20 & 0.80 & 0.11 & 3.71 \\
\hline $\mathrm{CaO}$ & 0.22 & 24.36 & 0.02 & 0.47 & 8.85 & 0.00 & 39.28 & 0.07 \\
\hline $\mathrm{Na}_{2} \mathrm{O}$ & 0.15 & 0.33 & 1.35 & 13.77 & 6.29 & 0.13 & 0.31 & 0.14 \\
\hline $\mathrm{K}_{2} \mathrm{O}$ & 0.00 & 0.04 & 28.83 & 10.55 & 0.76 & 16.95 & 0.08 & 0.00 \\
\hline $\mathrm{Cl}$ & 0.00 & 0.01 & 0.03 & 0.01 & 0.00 & 0.02 & 0.00 & 0.01 \\
\hline $\mathrm{P}_{2} \mathrm{O}_{5}$ & 0.00 & 0.11 & 0.00 & 0.00 & 0.00 & 0.00 & 0.00 & 0.00 \\
\hline Total & 99.95 & 99.66 & 100.22 & 99.88 & 99.79 & 99.56 & 100.01 & 98.94 \\
\hline \multicolumn{9}{|l|}{ Formula } \\
\hline \# of oxygens & $\mathrm{O}=4$ & $\mathrm{O}=6$ & $\mathrm{O}=32$ & $\mathrm{O}=32$ & $\mathrm{O}=32$ & $\mathrm{O}=32$ & $\mathrm{O}=3$ & $\mathrm{O}=32$ \\
\hline $\mathrm{Si}$ & 1.00 & 1.73 & 8.01 & 8.08 & 10.14 & 11.71 & 0.00 & 0.08 \\
\hline $\mathrm{Ti}$ & 0.00 & 0.11 & 0.01 & 0.01 & 0.06 & 0.02 & 0.99 & 6.02 \\
\hline $\mathrm{Al}$ & 0.00 & 0.26 & 7.63 & 7.73 & 5.69 & 4.13 & 0.01 & 0.80 \\
\hline $\mathrm{Cr}$ & 0.00 & 0.00 & 0.01 & 0.01 & 0.00 & 0.00 & 0.00 & 0.03 \\
\hline $\mathrm{Fe}^{3+}$ & - & - & - & - & - & - & - & 3.06 \\
\hline $\mathrm{Fe}^{2+}$ & 0.35 & 0.17 & 0.22 & 0.11 & 0.11 & 0.04 & 0.02 & 12.09 \\
\hline $\mathrm{Mn}$ & 0.01 & 0.01 & 0.01 & 0.00 & 0.00 & 0.00 & 0.00 & 0.22 \\
\hline $\mathrm{Ni}$ & 0.00 & 0.00 & 0.01 & 0.00 & 0.00 & 0.01 & 0.00 & 0.00 \\
\hline $\mathrm{Mg}$ & 1.65 & 0.75 & 0.07 & 0.04 & 0.05 & 0.22 & 0.00 & 1.60 \\
\hline $\mathrm{Ca}$ & 0.01 & 0.98 & 0.01 & 0.10 & 1.70 & 0.00 & 0.95 & 0.02 \\
\hline $\mathrm{Na}$ & 0.01 & 0.02 & 0.56 & 5.27 & 2.21 & 0.05 & 0.01 & 0.08 \\
\hline $\mathrm{K}$ & 0.00 & 0.00 & 7.80 & 2.66 & 0.18 & 4.05 & 0.00 & 0.00 \\
\hline $\mathrm{P}$ & 0.00 & 0.00 & 0.00 & 0.00 & 0.00 & 0.00 & 0.00 & 0.00 \\
\hline Total & 3.01 & 4.04 & 24.33 & 24.00 & 20.15 & 20.25 & 2.01 & 24.00 \\
\hline
\end{tabular}

Fo 82.4 En $\quad 38.7 \mathrm{Ne} \quad 6.7 \mathrm{Ne} \quad 66.5$ An $41.6 \quad$ An $\quad 0.0$

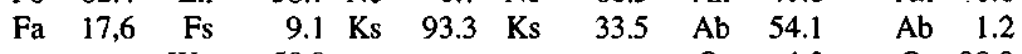

$\begin{array}{lllll}\text { Wo } & 50.9 & \text { Or } & 4.3 & \text { Or } 98.8\end{array}$

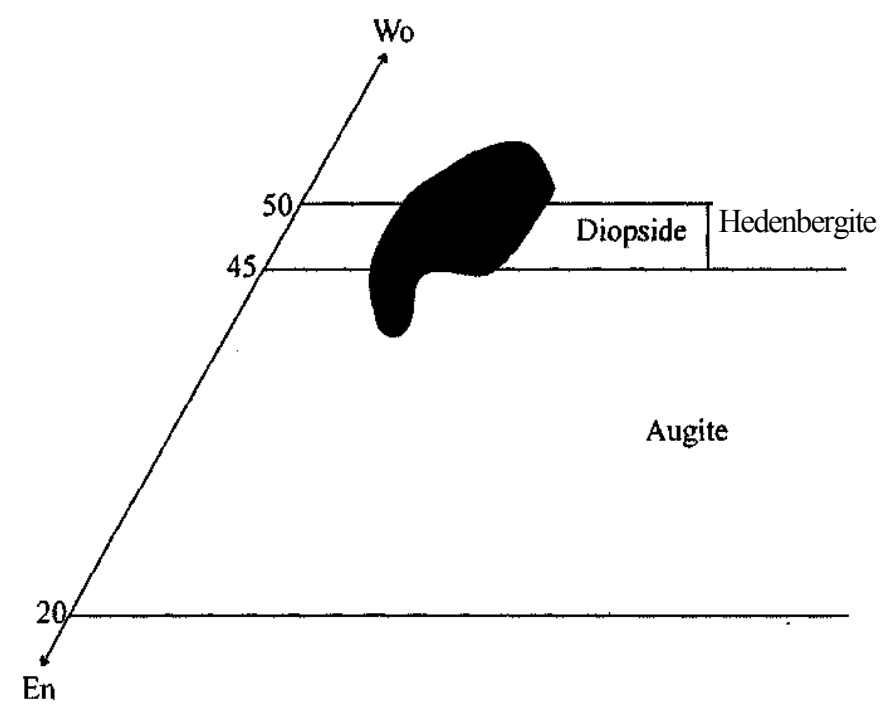

Figure 1-Classification of Águas Emendadas clinopyroxenes (after Morimoto et al. 1988). Data from Junqueira-Brod (1998), representative analysis is given in Table 1.

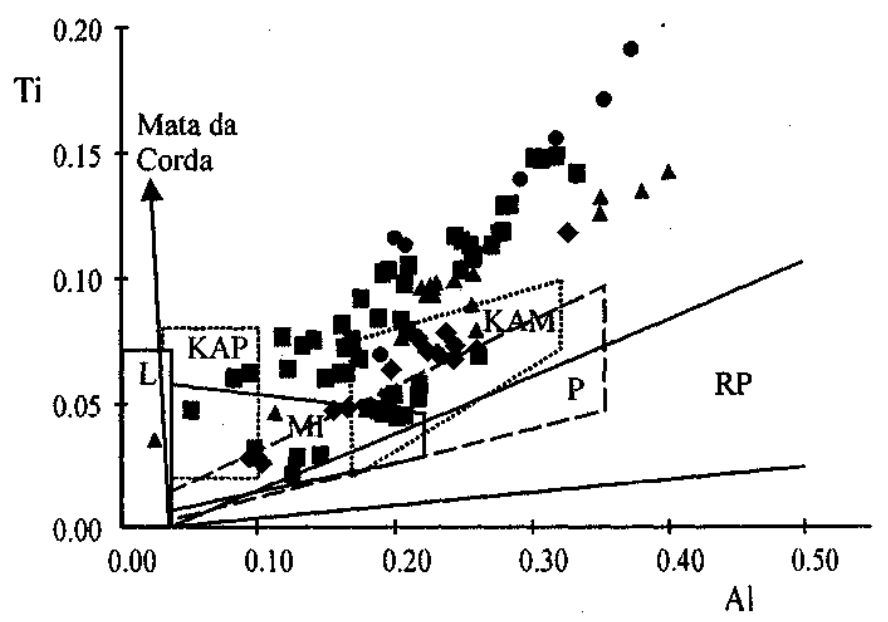

Figure 2-Al versus Ti variation of Águas Emendadas clinopyroxenes compared with pyroxenes of alkaline rocks from other localities. Lamproite (L), Kapamba (KAP), Minette (MI), Kamafugite (KAM) and Roman Province (RP) fields are from Mitchell and Bergman (1991). Mata da Corda kamafugites (trend indicated by arrow) from Sgarbi and Valença (1994). Paraguay (P) data from Cundari and Comin-Chiaramonti (1996). Data for all individual samples from Junqueira-Brod (1998): squares (melaleucitites), triangles (kamafugites), circles (leucitites) and diamonds (basanites). 
opaque minerals are part of the ulvöspinel-magnetite series. They are represented in Fig. 3, where most analyses plot near the titanomagnetite line, closer to the ulvospinel than to the magnetite endmember. Also significant, although highly variable, are $\mathrm{MgO}$ ( 0.33 to 10.23 wt.\%) $\mathrm{Cr}_{2} \mathrm{O}_{3}\left(0.08\right.$ to 17.61 wt.\%) and $\mathrm{Al}_{2} \mathrm{O}_{3}(0.37$ to 8.00 wt.\%). The highest $\mathrm{Mg}, \mathrm{Cr}$, and $\mathrm{Al}$ contents, representing some degree of solid solution towards $\mathrm{Mg}$-Al-chromites, are from one kamafugite and one leucitite sample.

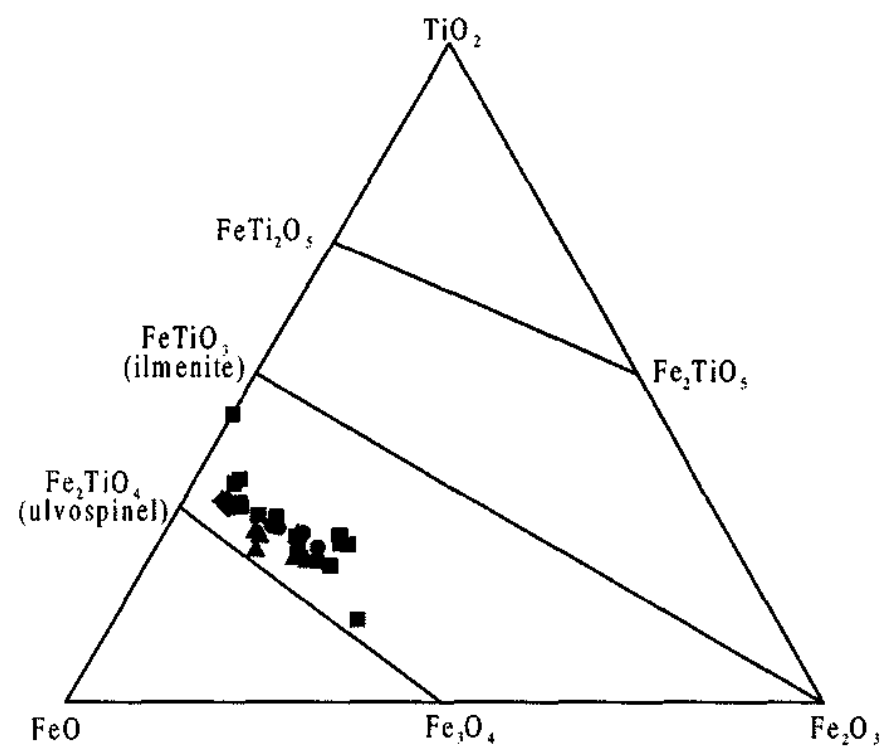

Figure 3-Compositional variation (mol\%) of Águas Emendadas oxides (after Deer et al. 1992) Data from Junqueira-Brod (1998), representative analysis is given in Table 1. Symbols as in Fig. 2.

Carbonate Carbonate minerals were not analysed by electron microprobe. However, since high trace-element contents of carbonates are considered an indication of their magmatic origin, two hand-picked separates of calcite from veins were analysed by ICP-MS at Durham University. Results are given in Table 2. The $\mathrm{Sr}$ and $\mathrm{Ba}$ contents range from 393 to $1596 \mathrm{ppm}$ and from 391 to $722 \mathrm{ppm}$, respectively. These figures are low, if compared with carbonates from carbonatites, where $\mathrm{Ba}$ and $\mathrm{Sr}$ are usually at percentage levels. Based on $\mathrm{Ba}$ and $\mathrm{Sr}$ concentrations alone, it would seem that the veins are a product of hydrothermal processes, rather than a direct manifestation of carbonatitic magmatism. However, chondrite-normalized REE patterns of these carbonates (Fig. 4) are parallel with the REE patterns of AER volcanic rocks, albeit at a lower concentration level. Unless the partition coefficients for different REE were the same in both the magmatic and the hydrothermal systems, this suggests a magmatic origin for the carbonates, and opens up the possibility of a kamafugitecarbonatite association at Águas Emendadas. A more detailed chemical and isotopic investigation of these carbonates is currently in progress, in order to establish or disprove their link with carbonatite magmatism.

CONCLUSIONS The presence of amoeboid inclusions of contrasting composition and/or texture within the lavas, dykes and magma pockets at AER diatremes strongly suggests that one or more episodes of magma mixing occurred prior to eruption. This is consistent with petrographic evidence for more than one generation of

Table 2-ICP-MS data for AER carbonates, results are given inppm

$\begin{array}{rrr}\text { Sample } & \text { 96AE37Cb } & 96 \text { AE38Cb } \\ \mathrm{Sr} & 393 & 1596 \\ \mathrm{Ba} & 722 & 391 \\ \mathrm{La} & 40.5 & 24.4 \\ \mathrm{Ce} & 74.5 & 45.2 \\ \mathrm{Pr} & 8.7 & 5.2 \\ \mathrm{Nd} & 33.1 & 19.7 \\ \mathrm{Sm} & 5.2 & 3.1 \\ \mathrm{Eu} & 1.47 & 0.93 \\ \mathrm{Gd} & 3.7 & 2.4 \\ \mathrm{~Tb} & 0.50 & 0.31 \\ \mathrm{Dy} & 2.36 & 1.51 \\ \mathrm{Ho} & 0.41 & 0.26 \\ \mathrm{Er} & 1.00 & 0.63 \\ \mathrm{Tm} & 0.14 & 0.09 \\ \mathrm{Ga} & 6.1 & 5.0 \\ \mathrm{Yb} & 0.83 & 0.53 \\ \mathrm{Lu} & 0.13 & 0.07\end{array}$

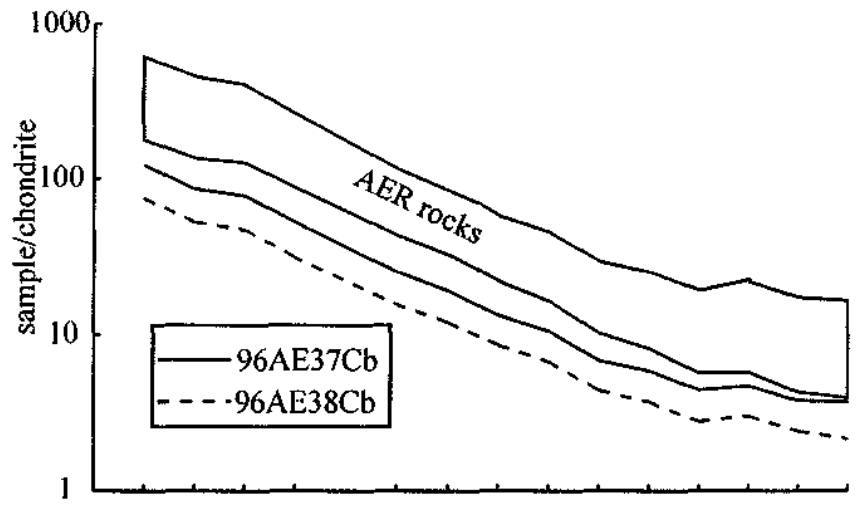

La Ce Pr Nd $\quad$ Sm Eu Gd Tb Dy Ho Er Tm Yb Lu

Figure 4-Chondrite-normalized REE diagram comparing carbonate REEpatterns with those from rocks of AER (data from Table 2). Normalization constants from Nakamura (1974), except Pr, Tb, Ho and Tm (Haskin et al. 1968).

olivine in some samples. The reverse zonirjg of some olivines suggests that some of the olivine phenocrysts were partly assimilated by more magnesian magmas. The Ti/Al ratio of AER pyroxenes is similar to that of the Ugandan kamafugites and distinct from Roman Provincetype rocks, Paraguayan alkaline rocks, and lamproites. The kamafugitic character of AER rocks is confirmed by the occurrence of kalsilite. The REE patterns of AER carbonates, and the relatively high $\mathrm{MnO}, \mathrm{CaO}$, low $\mathrm{NiO}$ content of some olivines suggests a link with carbonatite magmatism. The existence and nature of this link is currently under investigation.

Acknowledgements The authors would like to thank Dr. S. Reed, at Cambridge, Dr. C. J. Ottley and Mr. R. Hardy at Durham, for their help with the analysis, and Prof. O.H. Leonardos, at Brasília for his help during field work. JAB thanks CNPq (Grant 200.449/94-0) for financial support.

\section{References}

Almeida F.F.M. 1967. Origem e Evolução da Plataforma Brasileira. Boletim da Divisão de Geologia e Mineralogia, DNPM, Rio De Janeiro 241.

Almeida F.F.M. 1983. Relaçoes Tectonicas das Rochas Alcalinas Mesozoicas da Região Meridional da Plataforma Sul-Americana. Revista Brasileira de Geociências 13(3):139-158.

Almeida F.F.M. 1986. Distribuição Regional e Relações Tectônicas do Magmatismo PosPaleozoico no Brasil. Revista Brasileira de Geociências 16(4):325-349.
Barbour A.P., Girardi V.A.V., Kawashita K., Scares D., Souza A.M. 1979. Geocronologia do Complexo Máfico-Ultramá fico Älcalino de Santa Fé, Góias. Boletim do Instituto de Geociências, LISP, 10:11 -18.

Bez L., Guimaraes J.E., Guimaraes D. 1971. Distrito Vulcanico de Rio Verde. In: Congresso Brasileiro de Geologia, 25, São Paulo, Anais, 2:121-128.

Brod J. A. 1999. Petrology and Geochemistry of the Tapira Alkaline Complex, Minas Gerais State, Brazil. University of Durham, UK, Ph.D. Thesis, 486p. 
Brod J.A., Gibson S.A., Thompson R.N., Junqueira-Brod T.C., Seer H.J., Moraes, L.C., Boaventura G.R. 2000. The kamafughe-carbonatite association in the Alto Paranaíba Igneous Province (APIP), southeastern Brazil. Revista Brasileira de Geociências. (this volume)

Cundari A. \& Salviulo G. 1989. Ti solubility in diopsidic pyroxene from a suite of New South Wales leucitites (Australia). Lithos 22:191-198.

Cundari A. \& Comin-Chiaramonti P. 1996. Mineral chemistry of alkaline rocks from the Asuncion-Sapucai graben (Central-Eastern Paraguay). In: P. Comin-Chiaramonti \& C.B. Gomes (eds.), Alkaline magmatism in Central-Eastern Paraguay. Relationships with coeval magmatism in Brazil. São Paulo, Edusp/Fapesp, 181-193.

Danni J.C.M. 1978. Magmatic differentiation of the alkaline ultrabasic intrusions of the Ipora region, southwest Goiás, Brazil. In: International Symposium on Carbonatites, 1, Poços de Caldas, Proceedings, 149-167.

Danni J.C.M. 1985. Rochas da serie kamafugftica na regiao de Amorinopolis, Goiás. Contribuifoes a geologia e a petrografia -Niicleo de Minas Gerais - SBGM, Belo Horizonte, $5-13$.

Danni J.C.M. \& Caspar J.C. 1992. Mineralogia e quimica do katungito de Amorinopolis, Goiás. In: SBG, Congresso Brasileiro de Geologia, 37, São Paulo, Boletim de Resumos, 2:85-86.

Danni J.C.M. \& Caspar J.C. 1994. Quimica do katungito de Amoriridpolis - Goiás: Contribuicão ao estudo do magmatismo kamafuoitico Geochimica Brasiliensis, 8•119-134.

Danni J.C.M., Silva A.J.G.C., Campos J.E.G., Cerqueira M.R. 1992. Picritos Alcalinos do Sul de Goiás: Caracteristicas Mineralogicas e Geoquimicas. In:SBG, Congresso Brasileiro de Geologia, 37, São Paulo, Boletim de Resumos, 2:89.

Deer W.A., Howie R.A., Zussman J. 1992. An introduction to rock-forming minerals. Longman., 2nd ed., Essex.

Droop G.T.R. 1987. A general equation for estimating $\mathrm{Fe}^{3+}$ concentrations in ferromagnesian silicates and oxides from microprobe analyses, using stoichiometric criteria. Mineralogical Magazine 51:431 -435.

Caspar J.C. \& Danni J.C.M. 1981. Aspectos petrograficos e vulcanológicos da provincia alcalina-carbonatftica de Santo Antdnio da Barra, sudoeste de Goiás. Revista Brasi-

leira de Geociências, 11:74-83.

Caspar J.C., Araujo D.P, Mello M.V.L.C. 1998. Olivine in carbonatites and silicate rocks in carbonatite complexes. In: International Kimberlite Conference, 7, Cape Town, Extended Abstracts, 239-241.

Gibson S.A., Thompson R.N., Weska R.K., Dickin A.P., Leonardos O.H. 1997. Late Cretaceous rift-related upwelling and melting of the Trindade starting mantle plume head beneath western Brazil. Contributions to Mineralogy and Petrology, 126:303314.

Haskin L.A., Haskin M.A., Frey F.A., Wildman T.R. 1968. Relative and absolute terrestrial abundances of the rare earths. In: L.H. Ahrens (ed.), Origin and distribution of the elements, vol. 1. Pergamon, Oxford, 889-911.
Junqueira-Brod T.C. 1998. Cretaceous Alkaline Igneous Rocks from the Aguas Emendadas Region, Golds, Central Brazil. University of Durham, UK, M.Sc. Thesis, $161 \mathrm{p}$.

Junqueira-Brod T.C., Thompson R.N., Gibson S.A., Brod J.A. 1999. Volcanic and Pyroclastic Processes at The Aguas Emendadas Diatreme, Goiás. In: Simpósio sobre Vulcanismo e Ambientes Associados, 1, Gramado, Boletim de Resumos. 58

Mitchell R. H. 1996. Perovskites: a revised classification scheme for an important rare earth element host in alkaline rocks. In: A.P. Jones, F. Wall, C.T. Williams (eds.). Rare earth minerals: chemistry origin and ore deposits. Chapman \& Hall, London vol. 7,372 .

Mitchell R.H. \& Bergman S.C. 1991. Petrology of Lamproites. Plenum Press. New York, NY.

Moraes L.C. 1984. Petrologia estratigrafla e potencial diamantifero da suite vulcdnica alcalina da regiao de Santo Antonio da Barra, Goiás. Universidade de Brasília, M.Sc. Thesis, $133 \mathrm{p}$.

Moraes L.C. 1988. Aspectos petrologicos do magmatismo alcalino cretaceo de Santo An-

tonio da Barra, GO. Revista Brasileira de Geociencias 18:33-42.

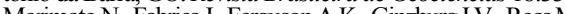
Aoki K., Gotardi G. 1988. Nomenclature of pyroxenes. American Mineralogist 73:1123-1133.

Nakamura N. 1974. Determination of REE, Ba, Fe, Mg, Na and K in carbonaceous and ordinary chondrites. Geochimica et Cosmochimica Acta 38:757-775.

Sgarbi P.B.A. \& Valenfa, J.G. 1994. Mineral and rock chemistry of the Mata da Corda kamafugitic rocks (MG State, Brazil).In: International Symposium on the Physics and Chemistry of the Upper Mantle, São Paulo, Extended Abstracts, 27-29.

Sgarbi P.B.A., Clayton R.N., Toshiko K.M., Caspar J.C. 1998. Oxygen isotope thermometry of Brazilian potassic volcanic rocks of kamafugitic affinities. Chemical Geology 146:115-126.

Tompkins L.A. 1987. Exploration for kimberlites in southwest Goiás region, Brazil: Mineral chemistry of stream sediment samples. Journal of Geochemical Exploration 27:128.

VanDecar J.C., James D.E., Assumpcão M. 1995. Seismic evidence for a fossil mantle plume beneath South America and implications for plate driving forces. Nature 378:25-31.
Contribution IGC-108

Received March 2, 2000 Accepted for publication May 10, 2000 